\title{
MIR22 Pre-miRNA
}

National Cancer Institute

\section{Source}

National Cancer Institute. MIR22 Pre-miRNA. NCI Thesaurus. Code C112485.

MIR22 pre-miRNA (85 bases) is encoded by the human MIR22 gene. This ribonucleotide may be involved in the regulation of transcription. 